\title{
Assessing of Modern Machinaries used by Large Scale Construction Firms for High Cost Construction Projects
}

\author{
S. Vinoth Kumar, C. Anish, S. Venkat Raman, K. Sathish Kumar
}

\begin{abstract}
India is one of fastest growing economy in the world which attracts many foreign investors to our country. With the economy being liberalized, foreign players have a vital stake over our countries growth and it's after effects. The Construction area has consistently been progressively to this financial development which all in all is an exceptionally divided industry. It needs to impart on a huge scale other related help business lines prone to be materials, types of gear, merchants, providers, subcontractors, customers and furthermore the undertaking plan and funds. All these elements which this sector deals with are subjected to potential risks involved which have to be predicted, monitored and managed. Construction industry has been following method for managing these risks and issues to be arising from a project. They have been managing these risks by foreseeing them with the experience and knowledge that the company has gained over the period of time. But this will be a question for a firm if they diversify or when they enter into any new venture of business domain. The conventional model is the one using the manual techniques for assessing risks involved from the experience, knowledge and competency gained in the business domain. Using Primavera (P6) the risk is been managed by creating several models generated which explains the process of additions of risks, identification of type of risk, calculation of exposure values, calculation of risk impact, assigning the person responsible to the risk, time frame of risk, preparation of control plans if the risk occurs. Finally the results thus obtained from both the methods are been compared and the results
\end{abstract}

Keywords - Foreign investors, Financial Development, Construction Industry

\section{INTRODUCTION}

Each undertaking carries with it certain components of hazard. The executives of these dangers and issues are significant in order to accomplish the targets of the task. For dealing with these dangers and issues, chance administration plan must be set up alongside development the executives plans. Development associations know the significance of undertaking the board and planning of a venture, they utilize a few strategies to survey the hazard engaged with the task.

Revised Manuscript Received on December 11, 2019.

S. VinothKumar, Department of Civil Engineering, Bharath Institute of Higher Education and Research, Chennai , India. Email: vinothsenna@gmail.com

C. Anish, Department of Civil Engineering, Bharath Institute of Higher Education and Research, Chennai , India. Email: anishdavidpaul@gmail.com

VenkatRaman,K, Department of Civil Engineering, Bharath Institute of Higher Education and Research, Chennai , India. Email: venkatraman.civil@bharathuniv.ac.in

K. Sathish Kumar, Department of Civil Engineering, Bharath Institute of Higher Education and Research, Chennai, India. Email: sathish_4549@yahoo.co.in
Over the years, there has been a significant demand for a positive attempt to ensure that construction projects are executed in accordance with the original intention for which such projects were conceived. Risk Management has been distinguished as an inescapable device to accomplish the above target[1]-[4].

Most of the construction projects depart from the original objectives for which they were conceived and this has exposed to risks. It is known that some clients and contractors have forfeited the employment of construction and project managers in a bid to cut cost. Even when they do employ construction managers, these managers have little or no knowledge in the areas of Risk Management. If these managers become responsible for the production of a construction project, they may have problems in the Contractual aspects of construction management[5]-[7]. When this occurs, the project from inception has a higher probability to deviate from prescribed quality, time and cost.

It is also known that despite the uniqueness of each construction project and its participants, there are certain recurring problems that cause disputes and misunderstanding. Such recurring problems which lead to disputes and misunderstanding among project participants can be traced to improper and poor understanding of Contractual conditions and the risk imbibed in them.

\section{Objectives}

The following are been identified as the objectives of this study

- To identify the various risks involved in a construction project.

- To discuss about conventional risk analysis method.

- To discuss about risk management using primavera.

- To compare both the techniques of risk management and to arrive on the conclusion.

\section{METHODOLOGY}

Below listed are the sequence in which the research work has been carried out:

- A sector and a project for which the risk to be assessed is been assumed.

- List of risks involved in the project are been identified.

- The project is been analysed for risk using the conventional analysis method. 


\section{Assessing of Modern Machinaries Used By Large Scale Construction Firms for High Cost Construction Projects}

- Then the entire project is been computed for risk using Primavera P6 for risk analysis.

- The results thus arrived are been compared and discussed[8]-[11].

\section{RESULTS AND DISCUSSIONS}

\begin{tabular}{|c|c|c|}
\hline PACKACE & $\begin{array}{l}\text { TYPE Or } \\
\text { DISK }\end{array}$ & $\begin{array}{l}\text { METHODTO } \\
\text { ANALYZE } \\
\text { RISK }\end{array}$ \\
\hline Goinlow. & 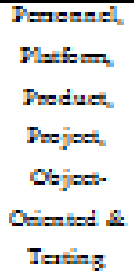 & $\begin{array}{l}\text { Rük Tese } \\
\text { Methed }\end{array}$ \\
\hline $\begin{array}{c}\text { bowpor hatisate } \\
\text { he. }\end{array}$ & 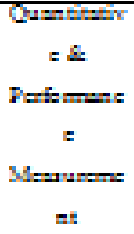 & $\begin{array}{l}\text { Exent Chain } \\
\text { Methedelegy }\end{array}$ \\
\hline heven Sign & $\begin{array}{l}\text { Qualitative } \\
- \\
\text { Qumetutix } \\
\text { e }\end{array}$ & $\begin{array}{l}\text { Mente Cele } \\
\text { Sïm latien }\end{array}$ \\
\hline Lix helligenes & All & $\begin{array}{l}\text { Advies er } \\
\text { Ialered } \\
\text { Methedx }\end{array}$ \\
\hline 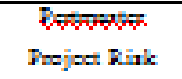 & $\begin{array}{c}\text { Quntitatix } \\
=\end{array}$ & $\begin{array}{l}\text { Mente Cele } \\
\text { Sïmlatien }\end{array}$ \\
\hline Dodies & All & $\begin{array}{l}\text { Mente Cele } \\
\text { Simulatien }\end{array}$ \\
\hline Popds & 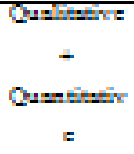 & $\begin{array}{l}\text { Mente Cele } \\
\text { Simulatien }\end{array}$ \\
\hline Danjext & Qualinative & Exens Chain \\
\hline
\end{tabular}

\begin{tabular}{|c|c|c|}
\hline $\begin{array}{c}\text { Decisions } \\
\text { Group }\end{array}$ & $\begin{array}{c}+ \\
\text { Quantitativ } \\
\mathrm{e}\end{array}$ & Methodology \\
\hline $\begin{array}{c}\text { Project Risk } \\
\text { Analysis (PRA) }\end{array}$ & $\begin{array}{c}\text { Contingenc } \\
\mathrm{y}\end{array}$ & $\begin{array}{l}\text { Monte Carlo } \\
\text { Simulation }\end{array}$ \\
\hline Risk Fighter & $\begin{array}{c}\text { Professiona } \\
1\end{array}$ & $\begin{array}{l}\text { PMBOK } \\
\text { Method }\end{array}$ \\
\hline Risk Trak & $\begin{array}{c}\text { Cost, } \\
\text { Schedule } \\
\text { and } \\
\text { Performanc } \\
\text { e }\end{array}$ & $\begin{array}{c}\text { ARM } \\
\text { Approach }\end{array}$ \\
\hline $\begin{array}{c}\text { Software } \\
\text { Program } \\
\text { ManagersNetw } \\
\text { ork }\end{array}$ & $\begin{array}{c}\text { Cost \& } \\
\text { Schedule }\end{array}$ & $\begin{array}{c}16 \text { Critical } \\
\text { SoftwarePracti } \\
\text { ces }\end{array}$ \\
\hline
\end{tabular}

Table 1: Comparisons of PM'S Software

- For managing these issues and risks, Information Technology offers many options. The various project management software's, which manages risks and issues, are as follows:

- Here as stated above are various Project Risk Management tools particularly used in our construction industry which we analyzed and finally chose Primavera P6 for our in depth study for the thesis.

- Primavera programming items are intended to help the undertaking the board needs of associations that oversee huge quantities of ventures one after another. Primavera helps us in identifying various risks involved in the project and it also tells us how to manage those. The incorporated risk the executives include in Primavera (P6) empowers us to recognize, order and organize potential dangers related with the particular work breakdown structure (WBS) components and assets[12]-[15]. We can likewise make risk control designs and relegate a likelihood of event and an authoritative breakdown structure (OBS) component to each hazard. A dangers relegated OBS component is the individual or task chief in charge of dealing with the risk.

\section{A. Risks Management Process}

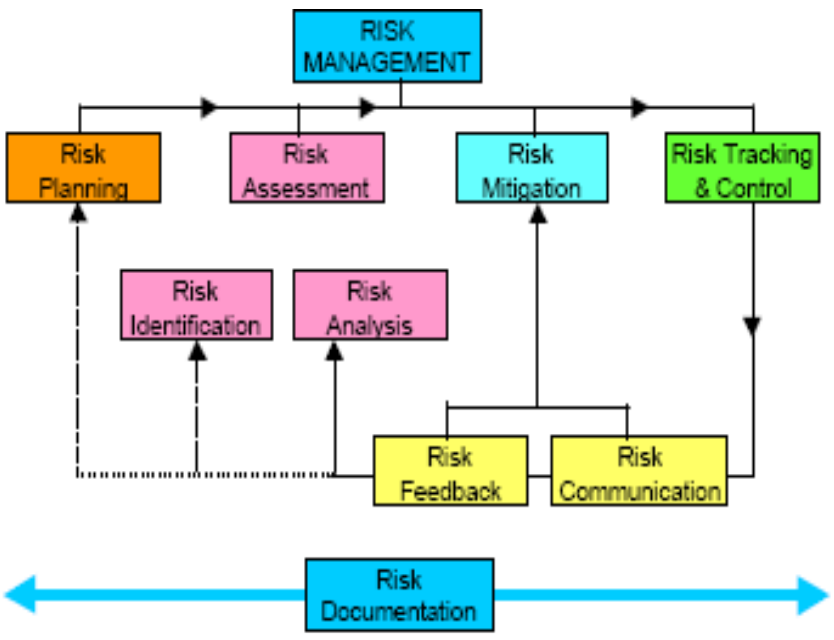

B. Types of Project Risks

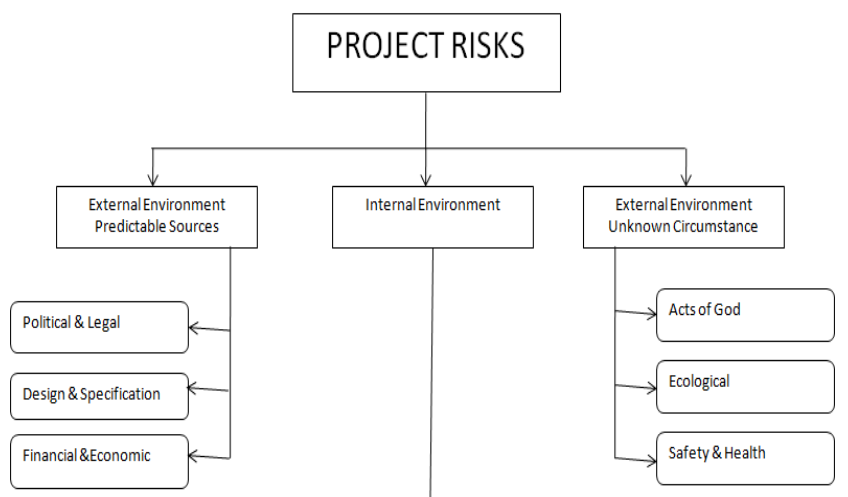




\section{Overview of Risk Management}

The process of Risk Management as illustrated above includes the following steps:

1. Explore uncertainties

2. Analyze the risks

3. Prioritize the risks

4. Mitigate the risks

5. Plan for Emergencies

6. Measure and Control

\section{Risk Assessment}

Risk Assessment is characterized in this examination as a method that expects to distinguish and gauge dangers to work force and property affected upon by legally binding conditions. Customary hazard evaluation for development has been synonymous with probabilistic examination. Such methodologies expect occasions to be totally unrelated, thorough, and restrictively autonomous[16]-[18]. In any case, development includes numerous factors, and it is regularly hard to decide setback, reliance and relationships. Thus, abstract traditional strategies that depend on verifiable data and the encounters of people and organizations have been utilized to evaluate the effect of Construction hazard and vulnerability.

\section{E. Determination of Risks}

There are two techniques to decide chance, to be specific the quantitative and the subjective methodology. The quantitative methodology depends on measurable figuring to decide hazard, its likelihood of event, and its effect on a task. A typical case of the quantitative methodology is choice tree investigation, applying probabilities to at least two results. Another methodology is the Monte Carlo reenactment, which creates an incentive from a likelihood dispersion and different elements.

The subjective methodology depends on decisions, utilizing criteria to decide result. A typical subjective methodology is a priority outlining strategy, which uses ordinal numbers to decide needs and results. A case of subjective methodology is to list in plunging request explicit procedures of a task, the hazard or dangers related with each procedure, and the control or controls that may or should exist for hazard[19]-[21].

\section{F. Risk Identification Tools And Techniques}

Agendas - Checklists are helpful, however are vigilant that they don't oblige imaginative or horizontal reasoning or real dangers might be neglected. The agenda additionally contains a way to deal with hazard prioritization, in view of likelihood and outcome investigation.

Conceptualizing - A typical technique that utilizations groups or gatherings to recognize a great deal of issues in a brief timeframe. Can help immensely in structure solidarity, sentiment of shared possession yet might be hard to get time duty.

Meetings - Interviewing individuals from the task group or pertinent topic specialists can distinguish dangers and help with understanding shifting viewpoints. It is absolutely profitable to 'draw in' with others and make them feel their

perspectives are significant and that they can add to the general arrangement[22]-[24].

Checking documentation/information sources - Risks can be distinguished by perusing arrangement or venture documentation, for example, RFI, offer reaction, venture history, venture brief, specialist's reports, delicate documentation, contracts from comparative arrangements or different circumstances with this client.

Partner examination - A powerful chance administration instrument is partner investigation. By this technique, we try to distinguish every one of those people or elements with a real enthusiasm for what we are going to do and shape that intrigue takes. In light of this examination, an arrangement can be grown how to address their issues/gain their help, how, what and when to impart. By getting issues, it is conceivable to be increasingly viable in tending to them with engaged and significant data that supports a fast choice.

Hazard reproduction - Risk reenactment procedures ordinarily include PC demonstrating, whereby "imagine a scenario where" situations are hurried to give a profile of the conceivable result of the circumstance. The outcomes can be indicated graphically to show the likelihood of the ideal result being accomplished.

Fishbone graph - This is a method for recognizing the conditions and factors that can add to an unwanted occasion. The components are broken into classifications, for example, individuals, machines, forms, outer occasions, and so on and conceptualizing is utilized to fill in the littler fish-bones and distinguish the particular factors liable to prompt a hazard turning into a reality[25]-[26].

\section{G. Project Study}

The details of the case study taken for discussion in this research paper are as shown below:

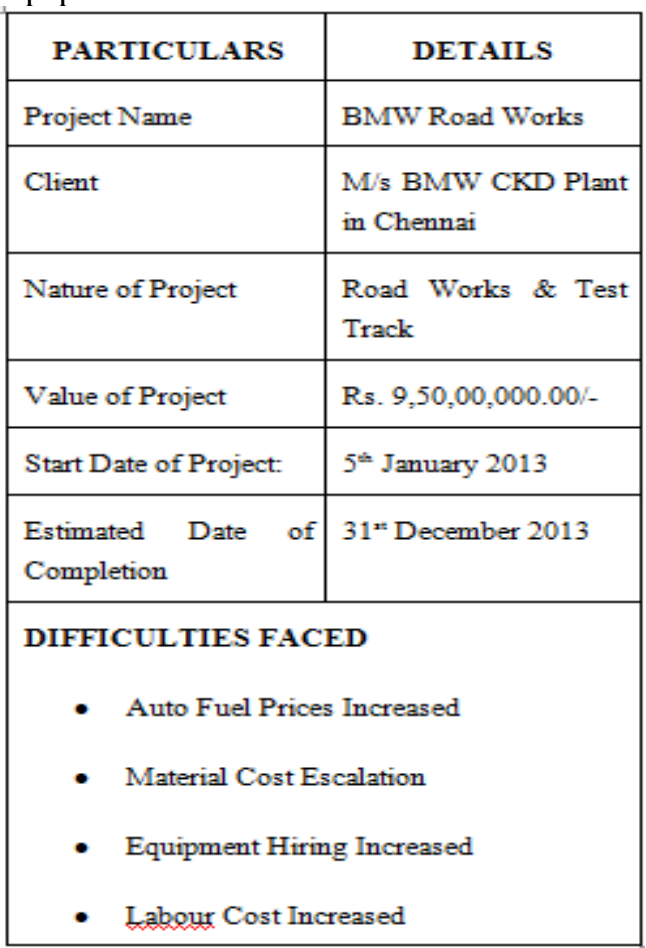




\section{CONVENTIONAL METHOD}

Conventional method of risk management involves experience; previous learning's and practices to calculate the risk that may arise in a project. This is a manual method which is done using MS-Excel package. This involves a company to be experienced in particular domain of work for a longer period to estimate the potential risk involved in that domain. Here risk is first identified, sorted on their priority and categorized, plans to mitigate then finally management of these risks[32]-[34].

The risks assessed in this method are as listed below:-
1) Machinery Risk
2) Manpower Risk
3) Material Risk
4) Time Risk

The case details given above are taken for details discussion. The entire risk is been calculated manually using MS-Excel package.

\section{V.PROJECT ANALYSIS}

In the above Table 5.4, there are two case conditions as discussed below:-

In Case 1

a. Defines the initial planning activity for Granular Sub-Base (GSB) preparation activity

b. With the project starting from 25-02-2013 and estimated end date as 21-04-2013, the cost of executing $1 \mathrm{CuM}$ of GSB work is Rs. 697.05/-

In Case 2

a. Defines the project deviation due to environmental and site conditions

b. With the same end date and project was delayed by 10 days

c. Thus the Project Schedule is been crushed which causes the following

i. Project to worked in double shifts which increases labour cost

ii. Thus increasing machinery overheads like idle charges, fuel charges, increased maintenance cost

d. Resulting the overall cost of 1Cum of GSB work to Rs. 818.17/-

\section{RISK MANAGEMENT USING PRIMAVERA (P6) INTRODUCTION TO P6}

Construction organizations use various project management software's for project management, among which is Primavera P6.

Primavera programming items are intended to help the undertaking the executives needs of associations that oversee enormous quantities of tasks simultaneously. These coordinated applications use venture portfolio the board (PPM) to help the administration needs of undertaking groups in various areas and at different degrees of the association.

The Project Management module empowers clients to follow and dissect execution. It is a multiuser, multi-venture framework with booking and asset control capacities supporting multi-layered task progressions, asset planning with an emphasis on jobs and abilities, recording of real information, adaptable perspectives and client determinable information[27]-[29].

\section{Terminology in risk impact}

Use the Risk Impact dialogue box to view the selected risks effect on the open projects schedule, cost and duration.

\section{WBS}

The code for the work breakdown structure (WBS), the risk will impact.

\section{Resource}

The resource the risk will impact.

\section{Impact Date}

The date the risk is expected to affect the open project.

\section{Impacted Activities}

The number of activities the risk will impact.

\section{Cost impact}

Current Labour Cost: The budgeted labour cost of the specified WBS element, without applying the risk.

Current Non-labour Cost: The budgeted non-labour cost of the specified WBS element, without applying the risk.

Current Material Cost: The budgeted material cost of the specified WBS element without applying the risk.

Current Expense Cost: The budgeted expense cost of the specified WBS element without applying the risk.

Impact Labour Cost: The impact labour cost of the specified WBS element without applying the risk.

Impact Non-labour Cost: The impact non-labour cost of the specified WBS element without applying the risk.

Impact Material Cost: The impact material cost of the specified WBS element without applying the risk.

Impact Expense Cost: The impact expense cost of the specified WBS element without applying the risk.

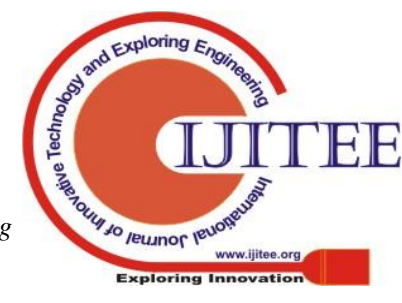


Current + Impact Labour Cost: The expected labour cost of the specified WBS element if the risks occur. This is the sum of the Current and the Impact Labour Cost fields.

Current + Impact Non-labour Cost: The expected non-labour cost of the specified WBS element if the risks occur. This is the sum of the Current and the Impact Non-labour Cost fields.

Current + Impact Material Cost: The expected material cost of the specified WBS element if the risks occur. This is the sum of the Current and the Impact Material Cost fields.

Current + Impact Expense Cost: The expected expense cost of the specified WBS element if the risks occur. This is the sum of the Current and the Impact Expense Cost fields.

Impact \%: For each item in this column, Impact \% is calculated as Impact divided by Current.

\section{The risk is calculated using:}

Exposure or Impact Cost $=$ Impact $\mathrm{x}$ Probability of occurrence of the event

Impact \% = Impact Cost / Current Cost

\section{Current Cost $=($ Total Materials Used $\mathrm{x}$ Material Rate $)-$ [(1-Probability)*Material Rate}

The Risk thus entered can be sorted, grouped and filtered. They can also be customized according to the project needs. For different project different category of risks can also be added and monitored as per the project schedule[30]-[36].

\section{CONCLUSION}

In any construction project it is very important to look out for risks involved in that project so that it can be handled easily and comfortably. However Construction Projects do not utilize Project Management Software rather they use manual techniques for computing the Risks involved. Still further study has to be carried out to extract the fullest potential of these Software Packages over the regular Conventional Techniques.

Below list are the recommendations and comparing in comparing both Conventional method and Primavera. These conclusions and recommendations are drawn with respect to the considered case study and corresponding to road projects. They are to be varying from project to project and from one sector to another.

- $\quad$ Conventional method provides a simple integration of risk involved in any project to be calculated by using manual technique with the experience gained in the industry and the nature of work. The risk estimated in this model can be done only if the project difficulties are know and the planner having previous experience.

- Thus the original estimate calculated by Conventional method estimated Rs. 697.05/- and revised estimate for the same work with project scheduled crashed due environment risks and site conditions is Rs 818.17/-

- Risk Management using Primavera is a fully automated method which does not need any manual calculations. Once the Project Schedule is be fed to the system with the necessary resources, items, milestone and other project requirement details, the system by itself will calculate if there is any risk arising.

- $\quad$ Finally, the magnitude and the quantum of risk involved in construction projects are of huge value. The delays damages and monetary values associated with these risks if they are not effectively managed will be almost the project cost. In live project scenario using any one of the methods alone will not stand effective, so a combination of both Conventional and Software has to be used to achieve an efficient project risk management plan and control. The choice of risk management tool also will depend on the type, natural and the impact associated with the risk to be monitored.

\section{REFERENCES}

1. Iyappan L., Dayakar P., Identification of landslide prone zone for coonoortalukusing spatial technology, International Journal of Applied Engineering Research,V-9,I-22,PP-5724-5732,Y-2014

2. Kumar J., Sathish Kumar K., Dayakar P.,Effect of microsilica on high strength concrete, International Journal of Applied Engineering Research,V-9,I-22,PP-5427-5432,Y-2014.

3. Dayakar P., Vijay Ruthrapathi G., Prakesh J., Management of bio-medical waste, International Journal of Applied Engineering Research,V-9,I-22,PP-5518-5526,Y-2014

4. Swaminathan N., Dayakar P., Resource optimization in construction project, International Journal of Applied Engineering Research,V-9,I-22,PP-5546-5551,Y-2014

5. Venkat Raman K., Dayakar P., Raju K.V.B.,An experimental study on effect of cone diameters in penetration test on sandy soil, International Journal of Civil Engineering and Technology,V-8,I-8,PP-1581-1588,Y-2017.

6. Saritha B., Chockalingam M.P.,Photodradation of malachite green DYE using TIO2/activated carbon composite,International Journal of Civil Engineering and Technology,V-8,I-8,PP-156-163,Y-2017

7. Shendge R.B., Chockalingam M.P., Saritha B., Ambica A.,Swat modelling for sediment yield: A case study of Ujjani reservoir in Maharashtra, India,International Journal of Civil Engineering and Technology,V-9,I-1,PP-245-252,Y-2018

8. Chockalingam M.P., Balamurgan V.,Modernisation of an existing urban road-sector in Chennai, a case study report,International Journal of Civil Engineering and Technology,V-8,I-8,PP-1457-1467,Y-2017

9. Saritha B., Chockalingam M.P.,Adsorption study on removal of basic dye by modified coconut shell adsorbent, International Journal of Civil Engineering and Technology,V-8,I-8,PP-1370-1374,Y-2017

10. Saritha B., Chockalingam M.P.,Adsorptive removal of heavy metal chromium from aqueous medium using modified natural adsorbent,International Journal of Civil Engineering and Technology,V-8,I-8,PP-1382-1387,Y-2017

11. Chockalingam M.P., Palanivelraja S.,Retrospective analysis of a theoretical model used for forecasting future air quality near the north Chennai thermal power plant,International Journal of Civil Engineering and Technology,V-8,I-8,PP-1457-1467,Y-2017

12. Saritha B., Chockalingam M.P.,Photodegradation of methylene blue dye in aqueous medium by Fe-AC/TiO2 Composite,Nature Environment and Pollution Technology,V-17,I-4,PP-1259-1265,Y-2018 
13. Shendge R.B., Chockalingam M.P., Kaviya B., Ambica A.,Estimates of potential evapotranspiration rates by three methods in upper Bhima Basin, In Maharashtra, India,International Journal of Civil Engineering and Technology,V-9,I-2,PP-475-480,Y-2018

14. Shendge R.B., Chockalingam M.P.,The soil and water assessment tool for Ujjani Reservoir,International Journal of Mechanical Engineering and Technology,V-9,I-2,PP-354-359,Y-2018

15. Shendge R.B., Chockalingam M.P.,A review on soil and water assessment tool,International Journal of Mechanical Engineering and Technology,V-9,I-2,PP-347-353,Y-2018

16. Sachithanandam P., Meikandaan T.P., Srividya T.,Steel framed multi storey residential building analysis and design,International Journal of Applied Engineering Research, V-9,I-22,PP-5527-5529,Y-2014

17. Meikandaan T.P., Ramachandra Murthy A.,Study of damaged RC beams repaired by bonding of CFRP laminates,International Journal of Civil Engineering and Technology,V-8,I-2,PP-470-486,Y-2017

18. Meikandaan T.P., Ramachandra Murthy A.,Retrofittng of reinforced concrete beams using GFRP overlays,International Journal of Civil Engineering and Technology,V-8,I-2,PP-423-439,Y-2017

19. Meikandaan T.P., Ramachandra Murthy A.,Flexural behaviour of RC beam wrapped with GFRP sheets,International Journal of Civil Engineering and Technology,V-8,I-2,PP-452-469,Y-2017

20. Meikandaan T.P., Murthy A.R.,Experimental study on strengthening of rc beams using glass Fiber,International Journal of Civil Engineering and Technology,V-9,I-11,PP-959-965,Y-2018

21. Meikandaan T.P., Hemapriya M.,Use of glass FRP sheets as external flexural reinforcement in RCC Beam,International Journal of Civil Engineering and Technology,V-8,I-8,PP-1485-1501,Y-2017

22. Saraswathy R., Saritha B.,Planning of integrated satellite township at Thirumazhisai,International Journal of Applied Engineering Research,V-9,I-22,PP-5558-5560,Y-2014

23. Saritha B., Ilayaraja K., Eqyaabal Z.,Geo textiles and geo synthetics for soil reinforcement,International Journal of Applied Engineering Research,V-9,I-22,PP-5533-5536,Y-2014

24. Ambica A., Saritha B., Changring G., Singh N B., Rajen M., Salman Md.,Analysis of groundwater quality in and around Tambaram taluk, Kancheepuram district,International Journal of Civil Engineering and Technology, V-8,I-8,PP-1362-1369,Y-2017

25. Arunya A., Sarayu K., Ramachandra Murthy A., Iyer N.R.,Enhancement of durability properties of bioconcrete incorporated with nano silica,International Journal of Civil Engineering and Technology,V-8,I-8,PP-1388-1394,Y-2017

26. Ilayaraja K., Krishnamurthy R.R., Jayaprakash M., Velmurugan P.M., Muthuraj S.,Characterization of the 26 December 2004 tsunami deposits in Andaman Islands (Bay of Bengal, India),Environmental Earth Sciences,V-66,I-8,PP-2459-2476,Y-2012

27. Ilayaraja K.,Morphometric parameters of micro watershed in Paravanar sub-basin, Cuddalore District,International Journal of Civil Engineering and Technology,V-8,I-8,PP-1444-1449,Y-2017

28. Ilayaraja K., Singh R.K., Rana N., Chauhan R., Sutradhar N.,Site suitability assessment for residential areas in south Chennai region using remote sensing and GIS techniques,International Journal of Civil Engineering and Technology,V-8,I-8,PP-1468-1475,Y-2017

29. Ilayaraja K., Reza W., Kumar V., Paul S., Chowdhary R.,Estimation of land surface temperature of Chennai metropolitan area using Landsat images,International Journal of Civil Engineering and Technology, V-8,I-8,PP-1450-1456,Y-2017

30. Chitra R.,Experimental study on beam using steel fiber and latex,International Journal of Civil Engineering and Technology,V-8,I-8,PP-1395-1403,Y-2017

31. Chitra R.,Analysis of traffic and management at Kovilambakkam intersection,International Journal of Civil Engineering and Technology,V-8,I-8,PP-1433-1443,Y-2017

32. Aswathy M.,Experimental study on light weight foamed concrete,International Journal of Civil Engineering and Technology,V-8,I-8,PP-1404-1412,Y-2017

33. Aswathy M.,Wastewater treatment using constructed wetland with water lettuce (Eichornia Crasipies),International Journal of Civil Engineering and Technology,V-8,I-8,PP-1413-1421,Y-2017

34. Kiruthiga K., Anandh K.S., Gunasekaran K, Assessment of influencing factors on improving effectiveness and productivity of construction engineers, 2015, International Journal of Applied Engineering Research, V - 10,I - $17, \mathrm{p}-13849-13854$.

35. Srinivasan, G.R. \& Palani, S. 2018, "Physicochemical analysis and economic evaluation of lake ecosystem - A case study of lake system in Walajah Taluk, Vellore (India)", Water and Energy International, vol. 61RNI, no. 3, pp. 52-55.

36. Srinivasan GR, Palani S, Manohanam A, Jambulingam R. Assessment of Groundwater Quality of Water Samples Collected From Vellore Co-Operative Sugar Mill, Vellore. Asian Man (The)-An International Journal. 2018;12(2):216-8.

\section{AUTHORS PROFILE}

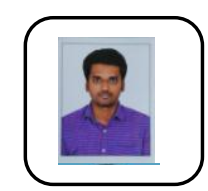

S. Vinoth Kumar Professor, Department of Civil Engineering, Bharath Institute of Higher Education and Research, Chennai, India.

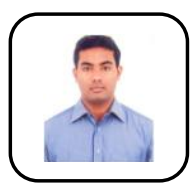

C. ANish Assistant Professor, Department of Civil Engineering, Bharath Institute of Higher Education and Research, Chennai, India.

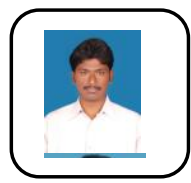

VenkatRaman,K Assistant Professor, Department of Civil Engineering, Bharath Institute of Higher Education and Research, Chennai, India.

Sathish Kumar . K Assistant Professor, Department of Civil Engineering, Bharath Institute of Higher Education and Research, Chennai , India. 